Summer 2014

\title{
Emerging Patterns of Global Constitutionalization: Toward a Conceptual Framework
}

Karolina Milewicz

University of Bern

Follow this and additional works at: https://www.repository.law.indiana.edu/ijgls

Part of the Constitutional Law Commons, and the International Law Commons

\section{Recommended Citation}

Milewicz, Karolina (2014) "Emerging Patterns of Global Constitutionalization: Toward a Conceptual Framework," Indiana Journal of Global Legal Studies: Vol. 16 : Iss. 2 , Article 3.

Available at: https://www.repository.law.indiana.edu/ijgls/vol16/iss2/3

This Symposium is brought to you for free and open access by the Law School Journals at Digital Repository @ Maurer Law. It has been accepted for inclusion in Indiana Journal of Global Legal Studies by an authorized editor of Digital Repository @ Maurer Law. For more information, please contact rvaughan@indiana.edu.

\section{$\Psi$}

JEROME HALL LAW LIBRARY

INDIANA UNIVERSITY

Maurer School of Law
Bloomington 


\title{
Emerging Patterns of Global Constitutionalization: Toward a Conceptual Framework
}

\author{
Karolina Milewicz*
}

\begin{abstract}
Global constitutionalization is a recent phenomenon that is decisively changing the character of the international order. This argument was put forward recently by scholars of international law and has gained significance in the institutional school of thought. However, the notion of "global constitutionalization" is often used imprecisely and has so far been largely neglected in the field of international relations. It still lacks a consistent and operational definition, which would enable political scientists and international relations scholars to conduct empirical research. This article explores a preliminary framework for the concept of global constitutionalization.
\end{abstract}

\section{INTRODUCTION}

An exploration of the patterns of global constitutionalization raises a number of important questions. What is a constitution? What is global constitutionalization? How do we get a handle on the concept? Whether their background is political or legal, researchers responding to the question "what does a constitution address?" primarily list characteristics that are typically associated with constitu-

* Ph.D. Candidate, Institute of Political Science, University of Bern; Research Fellow, National Centre of Competence in Research (NCCR) project on "International Trade Regulation: From Fragmentation to Coherence," World Trade Institute, University of Bern. This article was written in the context of the NCCR research project and is supported by the Swiss National Science Foundation. An earlier version of this paper was presented at the European Consortium for Political Research (ECPR) Joint Sessions, Helsinki, May 7-12, 2007. I would like to thank Anne Peters, Klaus Armingeon, André Bächtiger, Simone Peter, Nikolas Stürchler, Egle Svilpaite, Simon Niemeyer, the participants of the ECPR Helsinki workshop, and the anonymous reviewers for their generous and helpful comments.

Indiana Journal of Global Legal Studies Vol. 16 \#2 (Summer 2009)

CIndiana University Maurer School of Law - Bloomington 
tions in nation-states. Depending on the research objective, most scholars would consider the issues of written versus unwritten constitutions (writtenness), flexible versus rigid constitutions (rigidity), political revolution versus continuous evolution, the rule of law, division of powers, checks and balances, containment, the incorporated governmental structure, the hierarchy of law, and some basic political and civil rights as the fundamental features of a constitutional debate.'

When a definition of "global constitutionalization" is requested, no straightforward pattern-fitting reply can be expected. Initially, the concept of "constitutionalization beyond the state" was addressed in the context of European integration. ${ }^{2}$ However, processes of constitutionalization are not unique to the European Union (EU). Recently, the concept has gained considerable attention on the international plane. Scholars of international law concur that the normative idea of global constitutionalism and global constitutionalization are recent phenomena, decisively changing the character of the global order. When the need to define global constitutionalization arises, any attempt at a common definition causes disagreement. ${ }^{3}$

1. See generally Arend Lijphart, Patterns of Democracy: Government Forms and Performance in Thirty-six Countries (1999); Ruth Gavison, What Belongs in a Constitution?, 13 Const. Pol. Econ. 89 (2002); Anne Peters, Compensatory Constitutionalism: The Function and Potential of Fundamental International Norms and Structures, 19 Leiden J. INT'L L. 579 (2006); Giovanni Sartori, Constitutionalism: A Preliminary Discussion, 56 Am. Pol. ScI. Rev. 853 (1962).

2. European Constitutionalism Beyond the State (J.H.H. Weiler \& Marlene Wind eds., 2003).

3. Some researchers stress the blurred boundary between national politics and international law. In this manner, the core of constitutionalism is conceived by Thomas Cottier and Maya Hertig as interfacing different layers of governance from the local to the global level. See Thomas Cottier \& Maya Hertig, The Prospects of 21st Century Constitutionalism, 7 Max Planck Y.B.U.N.L. 261 (Armin von Bogdandy \& Rüdiger Wolfrum eds., 2003). For Frank Schorkopf and Christian Walter, global constitutionalism reflects the shift from an "actor-centered" concept of international law focusing on the regulation of relations between sovereign states, to a "subject-centered" understanding of international law denoting the regulation of specific subject matters, such as trade, security, and environments, and questions the boundary between general international law and national constitutional law. See Frank Schorkopf \& Christian Walter, Elements of Constitutionalization: Multilevel Structures of Human Rights Protection in General Intermational and WTO-Law, 4 German L.J. 1359, 1361, 1373 (2003). Anne Peters defines global constitutionalization as a legal instrument compensating for the ongoing de-constitutionalization on the domestic level. See Peters, supra note 1, at 580 . Though states are not considered to have ceased to be primary actors in the international system, the claim is that the role of states with respect to constitutional processes and objectives is being challenged by the forces of globalization or denationalization. See Dani Rodrik, Has Globalization Gone Too Far? (1997); James N. Rosenau, Along the Domestic-Foreign Frontier: Exploring Governance in a Turbulent World (1997); Michael Zürn, Regieren Jenseits des Nationalstaates (1998); Oliver Gerstenberg, Denationalization and the Very Idea of Democratic Constitutionalism: The Case of the European Community, Ratio Juris, Sept. 2001, at 298. In this sense, state constitutions no longer regulate the totality of governance in a comprehensive way and thus are no longer "total constitutions." 
Due to the variety of definitions proposed by scholars of international law, the concept of global constitutionalization still lacks clarity. Although its importance grew in the legal discipline and became the subject of discussion at the start of the twenty-first century, there is no consensus about the meaning of global constitutionalization. This is not only the case for the international law discipline, but also, and even more so, in the field of international relations.

Until recently, the concept of global constitutionalization was widely disregarded by scholars of international relations. The concept, however, concerns the scholarly sphere of international relations to the same extent as it does international law. Global constitutionalization must be taken into consideration when questions on the shape of the international order, ${ }^{4}$ as well as its determinants, are raised. From the viewpoint of an empiricist, it is important to translate this rather

Similarly, constitutionalism in neo-liberal tradition is seen as a shift from a statist to a global framework driven by globalist social forces, including non-state actors, with an interest in free trade (see, e.g., Michael H. Allen, Globalization and Peremptory Norms in International Law: From Westphalian to Global Constitutionalism?, 41 INT'L POL. 341 (2004)), which involves the "retreat of the state" and ascribes international agreements a quasi-constitutional effect (e.g., Stephen Gill, Constitutionalizing Inequality and the Clash of Globalizations, INT'L STud. Rev., Summer 2002, at 47, 59-60). Others apply the concept of global constitutionalization in the field of international trade by focusing on social practices to constrain political behavior, as well as the role of judicial power and review. See, e.g., Deborah Z. Cass, The Constitutionalization of the World Trade Organization: Legitimacy, Democracy, and Community in the International Trading System (2005); Robert Howse \& Kalypso Nicolaidis, Enhancing WTO Legitimacy: Constitutionalization or Global Subsidiarity?, 16 GovERNAnce 73 (2003); Hannes L. Schloemann \& Stefan Ohlhoff, "Constitutionalization" and Dispute Settlement in the WTO: National Security as an Issue of Competence, 93 Aм. J. INT'L L. 424 (1999); Bernhard Zangl, Is There an Emerging International Rule of Law?, 13 Eur. Rev. 73 (2005). By contrast, international constitutionalism, conceptualized in a more encompassing manner, refers to the fundamental structure and substantive norms of the international legal order as a whole (e.g., Erika de Wet, The Emergence of International and Regional Value Systems as a Manifestation of the Emerging International Constitutional Order, 19 LeIden J. INT'L L. 611 (2006); Joel P. Trachtman, The Constitutions of the WTO, 17 EUR. J. INT'L L. 623 (2006)), first focusing on the common constitutional principles, such as the separations of powers, the rule of law and arguably even democracy, and second by bringing international law into greater conformity with individual constitutional rights (see, e.g., Constitutionalism, Multilevel Governance and Social Regulation (Christian Joerges \& ErnstUlrich Petersmann eds., 2006); Ernst-Ulrich Petersmann, Human Rights, Constitutionalism and the World Trade Organization: Challenges for World Trade Organization Jurisprudence and Civil Society, 19 LEIDEN J. INT'L L. 634, 641 (2006)).

4. For a discussion of the international order and corresponding polarization of the concept of global constitutionalization and empire, see G. John IKenberry, After Victory: Institutions, Strategic Restraint, and the Rebuilding of Order after Major Wars 10-29 (2000); Jean L. Cohen, Whose Sovereignty? Empire Versus International Law, EтHICs \& INT'L AfF., Dec. 2004, at 1; Michael Zürn, Institutionalisierte Ungleichheit in der Weltpolitik. Jenseits der Alternative "Global Governance" versus "American Empire”, 48 Pol. ViertelJ. 680 (2007). 
normative concept into a consistent notion and a scientifically settled and operational definition that enables comparative political scientists and international relations scholars to conduct empirical research.

This article explores a preliminary conceptual framework of global constitutionalization with an eye toward approaching a consistent and scientifically operational definition of the concept that social scientists can cope with. The aim is not to prove the existence of global constitutionalization, nor to examine current developments in international law or the national and international conditions that might favor or hinder the emergence of a global constitutional setting. Rather, I discuss the basic, but essential, issue of how to conceptualize global constitutionalization so as to achieve an operational framework. Aiming at an operational scaffold for scholars of both political science and international relations, the underlying questions are: What are the basic characteristics of global constitutionalization? And how can these be captured empirically?

The article argues that global constitutionalization can be captured in terms of international relations as the "institutionalization of international norms," namely the process of the emergence, creation, and identification of constitutionlike elements. ${ }^{5}$ This parallels the historical evolution of human rights in domestic law and refers to a process through which international norms are established.

This article begins with the notions of constitution, constitutionalism, and constitutionalization as originally developed in the nation-state setting. If we are to speak of global constitutionalization, the typology must incorporate three fundamental constitutional elements. First, the emergence of a global constitution must be considered to be a continuous and lasting process, rather than an ad hoc event. Second, there must be a formal dimension that denotes some procedural and institutional norms that structure the legal system, that is, the rule of law. Third, global constitutionalization must have a substantive dimension associated with the guarantee of fairness and security. Combining these three elements, this article argues that the emergence of a global constitutional order can be divided into three temporally distinct sub-processes of global constitutionalization. While the constitutionalization of formal norms (formal constitutionalization) ${ }^{6}$ is expected to emerge first, substantive constitutionalization, the institutionalization of civil-political rights and, later, socio-economic rights, comes to the fore only at a second stage. The final stage stands for the most encompassing form of global

5. See de Wet, supra note 3, at 61 1-12; Peters, supra note 1, at 582; Petersmann, supra note 3; Zürn, supra note 4.

6. For the definition of types of global constitutionalization, see infra Part II. 
constitutionalization containing both formal and substantive elements (encompassing global constitutionalization). I conclude by stressing the operational viewpoints of such a global constitutional framework.

\section{Essential Concepts and Definitions}

To better understand what global constitutionalization is and how it differs from other related approaches, I first turn to the conceptual distinctions between the terms constitution, constitutionalism, and constitutionalization as originally defined in the nation-state setting.

\section{A. Constitution}

Although the term constitution is associated first and foremost with the nationstate, this notion lacks a clear and decisive definition. The understanding of this term differs according to national traditions. ' Sartori described the term constitution as something vague and not easily simplified. ${ }^{8}$ Many state constitutions, however, follow comparable Western templates, which have some basic principles and functions.

First, state constitutions are linked by some formal characteristics. Constitutions have emerged either through a constitutional big bang, which aimed to end political or social revolutions (as in France), ${ }^{9}$ or they were created to avert a revolution and restore certain pre-revolutionary conditions (as in the German Reich of 1871-1918). ${ }^{10}$ Still others have evolved over centuries, such as the British constitution."

A further essential element of a constitution is its writtenness. Although most state constitutions are written legal charters (exceptions include the British, Israeli and New Zealand constitutions), the notion of constitution cannot be bound only to its writtenness. ${ }^{12}$ In addition, a constitution is characterized by its precedence over

7. See Gavison, supra note 1, at 90; Ulrich K. Preuss, Constitutionalism, in Routledge EncrcloPedia of Philosophy (E. Craig ed., 1998), available at http://www.rep.routledge.com/article/ S013? ssid $=7454322428 \mathrm{n}=1 \#$.

8. See Sartori, supra note 1 , at 853.

9. See generally Orateurs de la Révolution française: Les Constituants (François Furet \& Ran Halévi eds., 1989).

10. See Ernst R. Huber, Deutsche Verfassungsgeschichte (1960).

11. See Peters, supra note 1, at 585. See generally George Burton Adams, Constitutional History of England (1934); William Stubes, The Constitutional History of England in Its Origin and Development: Selections (1979).

12. See generally Jon Elster, Forces and Mechanisms in the Constitution-Making Process, 45 Duke L.J. 364, 365 (1995). 
ordinary law, ensuring a special procedure for amending constitutional provisions and safeguarding it against modification through ordinary legislation or judicial review. ${ }^{13}$ In this sense, constitutions can have a different degree of rigidity. With respect to constitutional amendments, they can be constructed either as rigid constitutions or as flexible constitutions, depending on the required approval mechanism. ${ }^{14}$

Second, formal elements of a constitution imply that constitutions have to fulfill related procedural functions. Generally speaking, constitutions refer to the bulk of basic legal norms organizing and institutionalizing a polity, and therefore concern the regulation of the basic institutions of a polity that occupy the center of the community's life. ${ }^{15}$ Following Georg Jellinek, constitutions set in place politi$\mathrm{cal}$ institutions and define their competences. They lay down the terms of membership and the relation between the members and the community and regulate the institutions' core functions of lawmaking, conflict resolution, and law enforcement. ${ }^{16}$ In other words, constitutions constitute a political entity as a legal entity, organize it, limit political power, offer political and moral guidelines, justify governance, and contribute to integration. ${ }^{17}$

The link between constitutions and political institutions can also be captured by the concept of the rule of law as legally employed in the Anglo-American context. The rough equivalent used in Europe is known in German as Rechtsstaat or in French as état de droit. The rule of law reflects a common idea in the various concepts of constitution and means "that the state's bodies act according to the prescriptions of law, and law is structured according to principles restricting arbitrariness." 18 In a rule of law system the special relationship between the branches of power is guaranteed. Simply put, the set of formal rules that constitute law must be obeyed, implying that a political community lives under the rule of law and not under the rule of men. ${ }^{19}$ According to a standard formulation by

13. See James Bryce, Essay III: Flexible and Rigid Constitutions, in Studies in History and JurisPRUDENCE 124, 167-73 (1901).

14. See LijPharT, supra note 1 , at 218-23.

15. See Gavison, supra note 1, at 89; Peters, supra note 1, at 581, 585; Neil Walker, Postnational Constitutionalism and the Problem of Translation, in Europenn Constitutionalism Beyond the STATE, supra note 2, at 27, 33-35.

16. See Georg Jellinek, Allgemeine Stantslehre 505 (1914).

17. See Anne Peters, Elemente einer Theorie der Verfassung Europas $38-92$ (2001).

18. See András Sajó, Limiting Government: An Introduction to Constitutionalism 205 (1999).

19. Id. at 206; see H.L.A. HART, The Concept of Law (2d ed. 1994); José M. Maravall \& Adam Przeworski, Introduction to Democracy and the Rule of Law 1 (José M. Maravall \& Adam Przeworski eds., 2003). 
Lon Fuller, the list of formal requirements for this set of rules that constitute law, are norms that are general, publicly promulgated, not retroactive, clear and understandable, logically consistent, feasible, and stable over time. ${ }^{20}$

\section{B. Constitutionalism}

Constitutionalization should, in normative terms, account for more than simple formal elements regulating, in the international context, for example, relationships between nation-states as well as between nation-states and international organizations. Although constitutions restrict the will of authorities and prevent them from misusing power, neither a constitution nor the embedded idea of the rule of law are absolute categories. The very idea of restriction and containment implies that citizens are at the mercy of the government's impersonal and formal legal procedures. Strictly applied, a constitution and the historically narrow conception of the rule of law, as defined above, allow for no consideration of equity or the human condition. ${ }^{21}$

Therefore, it is important to address the term constitutionalism itself. ${ }^{22}$ Originally, constitutionalism described a political movement and an intellectual trend in the quest for a written constitution during the seventeenth and eighteenth centuries. It aimed at making the political power (monarchy) subject to law and at creating a government of laws and not of men. Today constitutionalism is a valueladen concept and refers to the inclusion of basic substantive principles. ${ }^{23}$

The concept of constitutionalism goes beyond the simple articulation of formal rules and procedures of a constitution. It defines rights of, and obligations to, individuals and thus refers to human dignity and the guarantee of fundamental rights to individuals. According to J.H.H. Weiler and Marlene Wind, constitutionalism "embodies the values, often non-stated, which underlie the material and institutional provisions in a specific constitution."24

By uncoupling the term constitutionalism from the notion of constitution, it is

20. See Lon L. Fuller, The Morality of Law 39 (1964).

21. See SAjó, supra note 18, at 207-11.

22. Cf. Gerhard Casper, Constitutionalism, in 2 Encyclopedia of the American Constitution 473 (Leonard W. Levy et al. eds., 1986); Preuss, supra note 7.

23. See Peters, supra note 1, at 582; see also Martti Koskenniemi, Constitutionalism as Mindset: Reflections on Kantian Themes About International Law and Globalization, 8 Theoretical INQuiRIES L. 8 (2007).

24. J.H.H. Weiler \& Marlene Wind, Introduction: European Constitutionalism Beyond the State, in European Constitutionalism Beyond the State, supra note 2, at 1, 3. 
possible to capture constitutionalism as a term connecting and accounting for a vindication of neo-Kantian values and the idea of Rechtsstaat. ${ }^{25}$ On the one hand, there is the formal rule of law. This is the institutionalization of procedures that refer to the concept of legality or legal authorization. On the other hand, there is the valueladen conception of the fundamental rights that should be guaranteed in a classic constitution. Therefore, unlike the notion of constitution, the principle of constitutionalism comprises both the requirement of legal certainty and the protection of acquired rights and legitimate expectations. Moreover, by including substantive elements, constitutionalism can both diminish the rule of law's one-sided inflexibility and the rule of law's alienation from real life. The idea of constitutionalism contains formal and substantive elements that together account for equality in the rule of law and the realization of equality in both form and content. ${ }^{26}$

\section{Constitutionalization}

Most written constitutions were developed in reaction to revolution or revolutionary movements pushing for a constitution. The accomplishment and refinement of a constitution is, in contrast, a long-term process taking into account the experience of constitutional violation, restriction of freedom and oppression, as well as the questionable practices of unsuccessful and despotic governments. It is precisely this requirement for process over time that can be derived from the principle of constitutionalization. Unlike the static language of the formal and substantive characteristics that form the basis of constitutionalism, constitutionalization indicates an underlying process. It embeds a time dimension, which means that a constitution or constitutional law can come into being as part of a process over time. Constitutionalization implies that a legal text can acquire or may eventually lose constitutional properties in a feedback process and can thus be a long-lasting development. It indicates a process encompassing the emergence, creation, and identification of constitution-like elements. In short, it denotes a constitution-in-the-making. ${ }^{27}$

Two further conceptual notes on constitutionalization are in order. First, while constiturionalism describes a "mindset" or what Weiler calls an "academic artifact"28 denoting what (international) law ought to be, constitutionalization describes the

25. Id.

26. See Sajó, supra note 18 , at 208, 217.

27. See Peters, supra note 1 , at 582.

28. J.H.H. Weiler, The Constitution of Europe 223 (1999); see Koskenniemi, supra note 23, at 18. 
concrete process of developing the (global) constitutional order. ${ }^{29}$ Second, constitutionalization should not be put on par with legalization. ${ }^{30}$ Although both concepts refer to the process of creating legal arrangements, they differ with regard to the type of legal process they induce and the scope of legal arrangements they cover. Legalization refers to the formal practices creating legal arrangements that gain binding force through bureaucratic details, such as precision, the degree of obligation, and the possibility of delegation. ${ }^{31}$ Constitutionalization, to the contrary, covers a much broader process. It not only refers to the formal process, ${ }^{32}$ but also political and social practices that establish law-like rules and institutions in the (international) community. ${ }^{33}$ Thus, it raises considerably more substantial questions about the systemic and substantive quality of international law. ${ }^{34}$

\section{Bringing It Together}

Starting from the nation-state perspective, this article has relied on the threefold distinction between constitution, constitutionalism, and constitutionalization. From this, it was possible to extract three elements that should be considered in conceptualizing a global constitutionalist framework. First, a constitutional system cannot exist without the rule of law; therefore, the concept of global constitutionalization should include some formal norms ensuring legitimate governance. Second, the rigidity of the rule of law system must be offset by substantive values that facilitate the effective endorsement of the public well-being of a politi-

29. See Richard Bellamy \& Dario Castiglione, Introduction: Constitutions and Politics, 44 PoL. STud. 413, 414 (1996); Andreas Fischer-Lescano, Redefining Sovereignty via International Constitutional Moments?, in Redefining Sovereignty: The Use of Force After the Cold War 335, 346 48 (Michael Bothe et al. eds., 2005).

30. See Kenneth W. Abbott et al., The Concept of Legalization, 54 InT'L Org. 401, 401 (2000).

31. Id.

32. See Martha Finnemore \& Stephen J. Toope, Alternatives to "Legalization": Richer Views of Law and Politics, 55 Int'L Org. 743, 750 (2001).

33. See Antje Wiener, Editorial: Evolving Norms of Constitutionalism, 9 Eur. L.J. 1, 8 (2003).

34. Constitutionalization as a process of creating constitution-like elements also contrasts with the moment of constitutional creation. The "constitutional moment" refers to the act of constitution-making in a revolutionary event. See Bruce Ackerman, Constitutional Politics/Constitutional Law, 99 YALE L.J. 453 (1989). In a recent contribution, Anne-Marie Slaughter and William BurkeWhite have denoted the fight against terror to be an "international constitutional moment." They argued that the global events following September 11, 2001 galvanized the international system to action in a short period of time, consequently giving rise to new rules transforming international norms on the prohibition of the use of force. See Anne-Marie Slaughter \& William Burke-White, The International Constitutional Moment, 43 Harv. INT'L L.J. 1 (2002). 
cal community. Finally, a framework for the emerging global constitutionalism must be tied to the idea of process and must not be restricted to the vision of attaining an exclusive final good that resembles a completed constitutional system. A global constitutional system is not an ad hoc event, but rather a process of continuous development.

\section{Constitutionalization Beyond the State}

Despite a discussion primarily rooted in the national setting, the terms constitution, constitutionalism, and constitutionalization are not exclusively applicable to the nation-state. ${ }^{35}$ It should be possible to transfer them to a setting beyond the nation-state following the three characteristics: the formal dimension; the substantive dimension; and the time dimension.

With regard to the international level, I refer to global constitutionalization as the process toward the institutionalization of international legal norms. Such a process implies the emergence, creation, and identification of two distinct constitutional elements that regulate international politics: institutional and organizational guidelines for interstate relations and fundamental human rights provisions for individuals. ${ }^{36}$ This process changes the character of the international order and brings about the normative idea of global constitutionalism-the idea that the rule of law and human rights protection exist on the global scale. Proceeding from the value premise of "normative individualism," several scholars define global constitutionalism according to a citizen's perspective. ${ }^{37}$ Such a value-laden constitutional reading is strongly linked to the recognition of individuals as the new subject of international law via the promotion of fundamental rights. ${ }^{38}$ This reading implies that modern

35. Cf. Neil Walker, The Idea of Constitutional Pluralism, Mod. L. Rev., May 2002, at 317.

36. See Gunther Teubner, Societal Constitutionalism: Alternatives to State-Centred Constitutional Theory?, in Transnational Governance and Constitutionalism 3, 17 (Christian Joerges et al. eds., 2004).

37. See, e.g., Ernst-Ulrich Petersmann, Constitutional Functions and Constitutional Problems of International Economic Law (1991); Richard Bellamy, The Political Form of the Constitution: The Separation of Powers, Rights and Representative Democracy, in Constitutionalism in Transformation 25, 43 (Richard Bellamy \& Dario Castiglione eds., 1996); Petersmann, supra note 3 , at 641 .

38. Bellamy, supra note 37, at 43; Ernst-Ulrich Petersmann, Multilevel Trade Governance in the WTO Requires Multilevel Constitutionalism, in Constitutionalism, Multilevel Trade GoverNance and Social Regulation, supra note 3, at 5,9. There is a rough parallel to the perception of constitutionalism as an "essentially liberal legalistic conception," which is "a formal framework of rights," on the one hand, and a "political and republican understanding of constitutionalism" that acknowledges the historically embedded role of politics as the "art of balancing, reducing and 
international law is no longer exclusively concerned with the regulation of state-tostate relations, but also with individual-state relations. ${ }^{39}$

In this sense, the emerging idea of global constitutionalism is considered to be a linkage of two specific sets of norms that evolve over time: the formal norms, which comprise primarily the principle of the rule of law, and the substantive norms, most importantly the guarantee of fundamental rights to individuals. ${ }^{40}$ By analogy to a domestic constitution, the global constitution is the sum of basic legal norms that comprehensively regulate the social and political life of an international polity. These legal norms establish the rule of law and guarantee certain liberties and rights. ${ }^{41}$

The most recent and prominent example of an emerging constitutional system beyond the nation-state is the attempt to set up a European constitutional order for the European Community (EC) and the EU. ${ }^{42}$ In addition, arguments in favor of global constitutionalization have been put forward with respect to global trade and the related establishment of the World Trade Organization (WTO). ${ }^{43}$

So far, little effort has been made to advance a comprehensive and operational framework of global constitutionalization. Depending on normative and disciplinary preferences, scholars have focused instead on single components of this concept. ${ }^{44}$ Law scholars may be inclined to view constitutionalization in merely formal or procedural terms. Liberal economists usually concentrate on the liberal aspects related to constitutionalism, while many social scientists focus primarily on the social and political instances of constitutionalization.

Despite widely varying readings of the global constitutional debate, two perceptions of global constitutionalization stand out: constitutionalization as a unitary and all-encompassing process on the one hand, and constitutionalization as an assembly of several differentiated processes on the other. Although in practice

managing conflicts," on the other. Bellamy \& Castiglione, supra note 29 , at 414 ; see also Bellamy, supra note 37, at 24.

39. See Hersch Lauterpacht, International Law and Human Rights 60-67 (1950).

40. Cf. Mattias Kumm, The Legitimacy of International Law: A Constitutionalist Framework of Analysis, 15 Eur. J. Int'L L. 907, 909 (2004).

41. Horst Dippel, Modern Constitutionalism, An Introduction to a History in Need of Writing, 73 Legal Hist. Rev. 153, 154 (2005).

42. See European Constitutionalism Beyond the State, supra note 2; Peters, supra note 17; Justine Lacroix, For a European Constitutional Patriotism, 50 PoL. STud. 944 (2002); Berthold Rittberger \& Frank Schimmelfennig, Explaining the Constitutionalization of the European Union, $13 \mathrm{~J}$. Eur. Pub. Pol. 1148 (2006).

43. See, e.g., Cass, supra note 3; Cottier \& Hertig, supra note 3; Howse \& Nicolaidis, supra note 3; Petersmann, supra note 3; Schloemann \& Ohlhoff, supra note 3; Schorkopf \& Walter, supra note 3; Trachtman, supra note 3; see also Petersmann, supra note 38, at 11-18.

44. Cf. Walker, supra note 35 , at 339-40. 
these positions fall more or less along a continuum, for illustrative purposes I simplify the situation by distinguishing between the two extremes. Some theoristsespecially European law scholars-understand constitutionalism as a concept that tries to establish international legal unity. ${ }^{45}$ In this respect, constitutionalism is about a legal integration of states. Several scholars have postulated a universal world constitution beyond the nation-state that is put into force by a world sovereign and legitimizes the exercise of global political power. In this regard, the U.N. Charter is referred to as the constitutional document of the international community. Accordingly, the United Nations is viewed as the primary institution that furnishes the international community with the necessary international organs. ${ }^{46}$

The alternative to constitutionalization in terms of global constitutional unity is global constitutional pluralism. Neil Walker-a staunch critic of global constitutional unity-argues that a range of different constitutional sites and processes exists. In his view, constitutionalism and constitutionalization are a "set of loosely and variously coupled factors" that allow one to distinguish between different forms of constitutionalism and to identify modes and degrees of constitutionalization. This contrasts with a constitutional reading in terms of black-and-white and all-or-nothing. ${ }^{47}$ For instance, Nico Krisch understands pluralism in the context of global administrative law as an alternative to the attempts at constitutionalizing the global political order into a coherent unified framework. He argues that a unified understanding of constitutionalization tends to downplay "the extent of legitimate diversity in the global polity." 48 This diversity is triggered, on the one hand, by the variety of global constituencies that cannot claim full regulatory legitimacy and, on the other hand, by the diverging ways of exercising participatory rights in the determination of the scope of the polity. ${ }^{49}$

Another strand of the pluralist conception is inspired by the sociological approach of Niklas Luhmann. Gunther Teubner, the most influential proponent of

45. See, e.g., de Wet, supra note 3; Bardo Fassbender, The United Nations Charter as Constitution of the International Community, 36 Colum. J. TRAnsnat'L L. 529, 533-34, 552 (1998); Peters, supra note 1.

46. See Bardo Fassbender, UN Security Council. Reform and the Right of Veto 86-87 (1998); Pierre-Marie Dupuy, The Constitutional Dimension of the Charter of the United Nations Revisited, 1 Max Planck Y.B.U.N.L. 1, 19 (1997); Ronald St. J. Macdonald, The Charter of the United Nations in Constitutional Perspective, 20 Austr. Y.B. INT'L L. 205, 206 (1999); Fassbender, supra note 45, at 567-68. But see, e.g., Teubner, supra note 36 , at 5.

47. Walker, supra note 35 , at 339-40.

48. Nico Krisch, The Pluralism of Global Administrative Law, 17 Eur. J. INT'L L. 247, 248 (2006).

49. Id. at 249 . 
the Luhmannian system theory within legal studies, describes the difference between constitutional unity and constitutional plurality:

The constitution of world society does not come about exclusively in the representative institutions of international politics, nor can it take place in a unitary global constitution which overlies all areas of society, but, instead, emerges incrementally in the constitutionalisation of a multiplicity of autonomous subsystems of world society. ${ }^{50}$

Global constitutional pluralism is thus associated with the emergence of different constitutional sites and processes that are configured in a horizontal, rather than a hierarchical and vertical, pattern..$^{51}$ It is concerned with the fragmentation of international law- - "the rise of specialized rules and rule-systems that have no clear relationship to each other" 52 - emerging from the horizontal nature of the international legal system. Constitutionalization, in this regard, does not seek to overcome fragmentation by creating legal unity in the international sphere, but rather attempts to adapt to it by acknowledging the fragmented nature of the international system. In other words, while global constitutional unity aims at the creation of the global unitary constitution, differentiated constitutionalization seeks to realize a multiplicity of autonomous subsystems in international politics. It suggests global constitutional plurality.

In this context it is crucial to distinguish between two debates. One focuses on the idealized distinction between unity and plurality of international law, and the other focuses on societal versus state-based constitutionalization. While this article focuses on the unity-plurality divide from a state-based perspective, it does not reflect on the role of societal forces (such as non-governmental actors) in the constitutionalization process. There are two reasons for this state-focused approach. First, current research is not able to quantify current societal developments in international relations. This prevents any empirical research on the topic. Second, even though societal actors might be pivotal in advocating global constitutionalization (for example, by stimulating the content of international law, setting the interna-

50. Teubner, supra note 36 , at 8 .

51. Walker, supra note 35, at 337; see also Gunther Teubner, "Global Bukowina": Legal Pluralism in the World Society, in Global Law Without a State 3 (Gunther Teubner ed., 1997).

52. International Law Commission, Report of the Study Group of the International Law Commission, Fragmentation of International Law: Difficulties Arising from the Diversification and Expansion of International Law, II 483, U.N. Doc. A/CN.4/L.682 (Apr. 14, 2006) (finalized by Martti Koskenniemi). 
tional legal agenda, promoting human rights, humanitarian and environmental law, or mobilizing states and leveraging public opinion), ${ }^{53}$ it is the states that produce international law. In this regard, Jean Cohen also argues that the importance of emerging societal forces is overestimated by systems theorists. According to Cohen, the "international society of states"-in contrast to the cosmopolitan order of societal forces-remains the core of the world political system..$^{54}$

\section{Steps Toward Global Constitutionalization}

In order to counteract the tendency to segregate constitutional aspects and to develop a comprehensive typology of global constitutionalization that captures the diversity, plurality and heterogeneity of the international order at the beginning of the twenty-first century, it is necessary to include both formal and substantive dimensions. At the same time, it is essential to take into account the underlying time dimension in a single framework. In referring to emerging global constitutionalism as a process of building up a legal order based on fundamental norms of a polity, we must understand that it is not only an encompassing and completed global constitutional system that ought to be labeled global constitutionalism; the intermediate steps representing the ongoing process of constitutionalization must be considered of equal importance.

\section{A. Formal Aspects of Global Constitutionalization}

Law at the international level, just as at the nation-state level, undergoes a process of organization and institutionalization. The principle of the rule of law refers in a strictly national context to the control and limit of political power, including a scheme of checks and balances achieved through the separation of powers. ${ }^{55}$ Translated to the international sphere, this implies that political entities must act within established legal frameworks and according to established procedures. It is a selection of rules providing an institutional setting with formal guidelines

53. See Civilizing World Society: Society and Community Beyond the State (Mathias Albert et al. eds., 2000); Steve Charnovitz, Nongovernmental Organizations and International Law, 100 Am. J. Int'L L. 348, 359-61 (2006); John W. Meyer et al., World Society and the Nation-State, 103 AM. J. Soc. 144 (1997).

54. Cohen, supra note 4 , at $13,24$.

55. See Fuller, supra note 20, at 33-94; HART, supra note 19; SAJó, supra note 18, at 205-06. 
for political and legal actions in the field of international relations. ${ }^{56}$ The principle of the rule of law empirically refers to relations between nation-states, and thus implies that international law is a regulatory instrument limited to the regulation of interstate relations. The rule of law principle, as embedded in the idea of constitutionalization, lends international law its formal character. ${ }^{57}$

Therefore, before becoming capable of constituting the substance of law, the formal principle of an international rule of law must be expressed in law. This process of establishing an international legal order is called formal constitutionalization (type $I$ in Table 1) and is considered to be the starting point of global constitutionalization. Examples include the U.N. Charter, the Vienna Convention on the Law of Treaties, and the Vienna Convention on Diplomatic Relations.

The establishment of norms regulating interstate relations may change nothing for individuals since they do not address the relationship among individuals or between individuals and states. These norms are, however, a necessary requirement for the guarantee of individual rights in the international community. In order to make a difference to the individual, it is essential to integrate the substantive dimension into the concept of global constitutionalization.

\section{B. Substantive Aspects of Global Constitutionalization}

The substantive dimension embodied in the concept of constitutionalization refers to the international protection of fundamental human rights. ${ }^{58}$ In contrast to the formal understanding of international law based on the old doctrine of state sovereignty, which was mainly devoted to the immunities of states, their diplomatic representatives, and their property, the emergence of international fundamental rights is a rather recent phenomenon. It goes hand in hand with the recognition of the individual as the ultimate subject of modern international law by acknowledgement of fundamental rights. Thus, the recognition of human rights is synonymous with the recognition of the individual as the subject of international law. It implies that modern international law is no longer exclusively concerned with the regulation of state-to-state relations but also with relations between the individual and the state. Further, it brings to mind that the often

56. John H. Jackson, Sovereignty, the WTO and Changing Fundamentals of International Law 45 (2006); Henry J. Steiner \& Philip Alston, International Human Rights in Context 990 (2d ed. 2000).

57. See LaUter Pacht, supra note 39 , at 60-67.

58. Cf. Christian Tomuschat, Human Rights: Between Idealism and Realism (2003). 
conflicting collective good, as represented internally and externally by the sovereign, is conditioned by the goods of the individual human beings who compose the collectivity. ${ }^{59}$ I call this constitutional component substantive since international law functions in this respect as a patron and safeguard of fundamental rights granted to individuals.

When referring to fundamental human rights, it is unavoidable to speak of human rights in terms of "generations," ${ }^{60}$ implying that international human rights have evolved throughout history following a temporal sequence. Although this generational concept is far from being a popular theoretical and analytical tool in scholarly literature, it is a useful framework for the purpose of conceptualizing the emerging patterns of global constitutionalization.

International human rights are considered to be the "offspring of the human rights that were originally codified at the national level."61 The substance of what was first guaranteed within a national framework was only later adopted in an international set of rules. ${ }^{62}$ With regard to the national level, Thomas Marshall conceptualizes human rights by the notion of citizenship. ${ }^{63} \mathrm{He}$ distinguishes between civil, political, and social citizenship, the last denoting a range of rights ensuring a basic minimum of economic welfare and security. ${ }^{64}$ Following this, the earliest version of cirizenship was conceived of as a collection of civil rights, which were subsequently supplemented by political rights and, lastly, by social rights.

Like Marshall, the international law scholar Karel Vasak makes a similar dis-

59. See LaUterpacht, supra note 39 , at 61-67.

60. Note that the generational account of rights is often associated with the conception of negative and positive rights. Negative rights come close to the first generation of human rights. They prohibit certain government actions. Positive rights correspond to the second and third generations of human rights. They impose moral obligations on governments to provide public goods and services. See Isaiah Berlin, Two Concepts of Liberty, in LinerTy 166-81 (Isaiah Berlin \& Henry Hardy eds., 2002). Negative and positive rights should be not confused with claim rights and liberty rights. Both liberty and claim rights can take on positive and negative features. Claim rights impose a duty or obligation for a party. Liberty rights, by contrast, are associated with a freedom from duty. A positive claim right is the duty of one party to do something for another party, and a negative claim right is the duty of one party to refrain from doing something to another party. The freedom to do something is a positive liberty right, the freedom to refrain from doing something is a negative liberty right. See generally John Finnis, Natural Law and Natural Rights 198-205 (1980).

61. Tomuschat, supra note 58 , at 25.

62. Id.

63. See generally Thomas H. Marshall, Citizenship and Social Class (1950). For a description of the nation-based development of human rights, see also Toмuschat, supra note 58 , at 70-83.

64. Marshall, supra note 63. Cf. Ralf Dahrendorf, Citizenship and Beyond: The Social Dynamics of an Idea, 41 Soc. Res. 673 (1974); Ralf Dahrendorf, A Precarious Balance: Economic Opportunity, Civil Society, and Political Liberty, Responsive CMtY., Summer 1995, at 13. 
tinction. ${ }^{65}$ Drawing on the French Revolution, he differentiates between three generations of international human rights: liberté (civil and political rights, first generation); égalité (economic, social, and cultural rights, second generation); and fraternité (solidarity rights, third generation) ${ }^{66}$ Finding their expression in the Universal Declaration of Human Rights, human rights of the first generation are civil and political liberties. When referring to human rights of the second generation, one means economic and social rights.

As the process of global constitutionalization is also expected to embrace substantive norms, civil-political as well as socio-economic rights are considered to be integral parts of this development in international law. I call the institutionalization of international human rights provisions substantive constitutionalization (type II in Table 1).

\section{Civil-Political Dimension of Constitutionalization}

Most contemporary scholars view civil and political rights as being prior and primary when compared to social and economic rights. ${ }^{67}$ They are considered to be the first generation of rights dealing exclusively with the concern of liberty as expressed in freedom of speech, movement, and religion, security of person, and

65. Karel Vasak, $A$ 30-Year Struggle, UNESCO Cour., Nov. 1977, at 29.

66. Human rights of the third generation comprise rights such as the right to development, peace, environmental protection, and self-determination. In contrast to rights of the first and second generation, these collective rights have not yet reached the formal status of "hard law" and thus do not find expression in international law documents, but rather have the nature of political proposals (cf. Tomuschat, supra note 58, at 24; Cécile Fabre, Constitutionalising Social Rights, 6 J. Pol. PHIL. 263 (1998)) and are not considered further here.

67. Note that issue of priority among types of human rights is subject to controversy. See CharLes Fried, Right and Wrong 178 (1978); Ruth Gavison, On the Relationship Between Civil and Political Rights, and Social and Economic Rights, in The Globalization of Human Righrs 23, 36 (JeanMarc Coicaude et al. eds., 2003). Hugo Bedau and Maurice Cranston argue that due to the essentially negative character of first generation rights, traditional civil and political rights deserve priority over social and economic rights. See Maurice Cranston, What Are Human Rights? (1964); Hugo A. Bedau, Human Rights and Foreign Assistance Programs, in Human Rights and U.S. Foreicn Policy 29, 35 (Peter G. Brown \& Douglas MacLean eds., 1979). Henry Shue, on the other hand, maintains that the distinction between negative and positive rights bears no moral significance. He argues that all human rights have both negative and positive components. See Henry Shue, Basic Rights: Subsistence, Affluence, and U.S. Foreign Policy $35-37$ (1980); Henry Shue, Rights in the Light of Duties, in Human Rights and U.S. Foreign Policy, supra at 65, 71-75. Also, according to the U.N. ideology, human rights are regarded to be "interdependent and indivisible." See Universal Declaration of Human Rights, G.A. Res. 217A, at 71, U.N. GAOR, 3d Sess., 1st plen. mtg., U.N. Doc. A/810 (Dec. 12, 1948). 
the right to political participation. ${ }^{68}$ From a historical, national perspective, citizenship in its earliest version included civil rights comprised of the rights necessary for the freedom of the individual-liberty of the person, liberty of thought, and liberty of faith, the right to own property and to conclude valid contracts, and the right to justice. ${ }^{6}$

However, since civil rights are bound to remain empty promises for those who lack not only the economic means to make use of them, but also the political rights to make sure that the rule of law is not systematically turned to the advantage of some groups over others, political rights have emerged over time to supplement civil rights. This political element stands for the right to participate in the exercise of political power and the guarantee of political freedom, including the right to vote, to stand for election, to form political groups, and to voice political views freely. ${ }^{70}$ These political rights are important additive elements that enrich the global constitutional order.

The civil-political dimension of constitutionalization indicates the simultaneous emergence of civil and political rights. With regard to the international context, human rights of the first generation do not imply that a global political citizenship - with citizens equipped with the right to vote for international governing bodies-is feasible. Rather, these rights indicate the opportunity for individuals to claim their personal freedoms, such as the right to seek redress if injured by another, the right of peaceful protest, and the right to a fair investigation and trial if suspected of a crime. This concept also refers to equal treatment of individuals irrespective of race, sex, or class. In other words, institutionalization of civil and political rights means that individuals are protected from the coercive power of governing authorities and are granted the liberty to participate in (international) politics. Civil and political rights are concerned with individual freedoms, implying the negative right not to be interfered with in forbidden ways. ${ }^{\text {" }}$ The international institution most concerned with basic standards of personal liberties is the Human Rights Committee, ${ }^{72}$ a U.N. entity comprised of a body of

68. See Jack Donnelly, The Concept of Human Rights $61-67$ (1985); Daniel Kaufmann, Human Rights and Governance: The Empirical Challenge, in Human Rights and Development: Towards Mutual Reinforcement 352 (Philip Alston \& Mary Robinson eds., 2005).

69. Tомuschat, supra note 58, at 24; Fabre, supra note 66, at 265.

70. See Dahrendorf, Citizenship and Beyond, supra note 64, at 680-81.

71. See Fried, supra note 67, at 110.

72. The United Nations Commission on Human Rights was replaced as of March 15, 2006 by the newly created United Nations Human Rights Council. G.A. Res. 60/251, U.N. Doc A/RES/60/251 
independent experts that monitors implementation of the International Covenant of Civil and Political Rights by the state parties.

\section{Socio-Economic Dimension of Constitutionalization}

Substantive global constitutionalization cannot be limited to civil and political rights. Although this category of rights is awarded primacy because it is concerned with individual freedoms, ${ }^{73}$ it, too, is bound to remain insufficient so long as economic and social differences prevent people from acquiring the means to exercise their liberties.

At the beginning of the twenty-first century, increasingly global transactions call for the consideration of redistributive aspects addressing "new global risks." These risks are related to the principle of equality, which finds expression in the second generation of human rights. These rights are social and economic in nature. Social and economic rights pursue the creation of a level playing field for all individuals by setting common standards with regard to economic liberalization as well as social development. ${ }^{74}$

Economic rights ${ }^{75}$ comprise market-enabling measures aimed at the abolition of protectionist rules and the redress of inequality of opportunities for economic activity between citizens of different nations. ${ }^{76}$ The creation of the Internal Market of the European Community, the WTO and its General Agreement on Tariffs and Trade (GATT), the General Agreement on Trade in Services (GATS), and the Agreement on Trade Related Aspects of Intellectual Property Rights (TRIPS) are major examples of such a "negative integration." Economic rights brought about by the WTO can be seen as important means of global constitutionalization.

(Apr. 3, 2006), available at http://www2.ohchr.org/english/bodies/hrcouncil/docs/A.RES.60.251_ En.pdf.

73. Gavison, supra note 67 , at 69.

74. Tомuschat, supra note 58, at 24; Fabre, supra note 66, at 265.

75. Recent literature has also pointed to economic rights as elements of an enlarged concept of civil rights, indicating the right to trade and the right to market access, as well as the protection of civil liberties and properties. See Claude E. Barfield, Free Trade, Sovereignty, Democracy: The Future of the World Trade Organization (2001); Tom Bottomore, Citizenship and Social Class, Forty Years On, in T.H. Marshall \& Tom Bottomore, Citizenship and Social Class 55 (1992); Ernst-Ulrich Petersmann, From "Negative" to "Positive" Integration in the WTO: Time for "Mainstreaming Human Rights" into WTO Law?, 37 Coмmon Mкт. L. Rev. 1363 (2000).

76. Donnelly, supra note 68, at 90-96; Tomuschat, supra note 58 , at 24 ; Fabre, supra note 66 , at 265; Kaufmann, supra note 68. 
However, economic liberties may damage the individuals' social rights. One could even argue that, while economic rights, in constitutional terms, protect individuals by creating a level playing field, they simultaneously damage the principle of protection of the individual because individuals are now exposed to international markets and thus are much more vulnerable than in a closed economy. ${ }^{77}$ Liberalization is acceptable only if there is concomitantly some sort of compensation offered in the field of labor and social security.

Therefore, social rights must also be considered. Social rights are rights to claim some limited goods, ${ }^{78}$ such as the right to work, education, health care, social security, and a minimum standard of living. Social rights provide a response to these new requirements. These rights also include social provisions covering the risks of loss of income after retirement or during periods of unemployment. ${ }^{79}$ In contrast to the establishment of economic rights via the liberalization policies of the WTO, the creation of social security implies the setting of common standards. Arguably, the international institutions that are most concerned with the setting of basic social standards are the International Labour Organization (ILO), the World Health Organization (WHO), and the Food and Agriculture Organization of the United Nations (FAO).

In sum, global constitutionalization is closely linked to the substantive idea of fundamental rights of the first and second generations as well as the formal principle of the rule of law. Since global constitutionalization is not an ad hoc event, but rather a long-term process consisting of intermediate stages, its elements can be divided into three sub-processes. At the first stage, the emergence of the formal aspect should become visible. At the second stage, global constitutionalization is supplemented by substantive rights, comprised primarily human rights of the first generation and followed by human rights of the second generation. Combining basic civil liberties and political freedoms, the substantive constitutional norms meet in the form of the civil-political dimension of global constitutionalization. Only then do social and economic rights of the second generation enter the field. Since economic rights threaten the individual's right to social security, and social rights endanger the individual's right to economic freedom, they can be considered both conflicting

77. See Peter J. Katzenstein, Small States in World Markets: Industrial Policy in EuROPE (1985); David R. Cameron, The Expansion of the Public Economy: A Comparative Analysis, 72 AM. Pol. Sci. Rev. 1243, 1251 (1978).

78. Cf. FRIED, supra note 67 , at 110.

79. Томuschat, supra note 58, at 24; Fabre, supra note 66, at 265. 
and subsidiary in nature. Supplementation with this socio-economic constitutional dimension accomplishes the process of substantive constitutionalization.

Global constitutionalization, in its final stage, encompasses both formal and substantive entities, the latter being based on the effective institutionalization of civil and political rights as well as of economic and social rights. This encompassing global constitutionalization (type III in Table 1) represents a combination of formal norms guiding interstate relations and the institutionalization of human rights provisions for individuals. It is a manifestation of the balancing between individual and collective rights, positive and negative rights, and formal mechanisms and substantive norms.

TABLE 1: Types of Global Constitutionalization

\begin{tabular}{|c|c|c|c|}
\hline \multirow{4}{*}{$\begin{array}{l}\text { Institutionalization of } \\
\text { substantive provisions } \\
\text { (human rights for } \\
\text { individuals) }\end{array}$} & \multicolumn{3}{|c|}{$\begin{array}{l}\text { Institutionalization of formal norms } \\
\text { (procedural guidelines for interstate relations) }\end{array}$} \\
\hline & & No & Yes \\
\hline & No & No constitutionalization & $\begin{array}{l}\text { I. Formal } \\
\text { constitutionalization }\end{array}$ \\
\hline & Yes & $\begin{array}{l}\text { II. Substantive } \\
\text { constitutionalization }\end{array}$ & $\begin{array}{l}\text { III. Encompassing global } \\
\text { constitutionalization }\end{array}$ \\
\hline
\end{tabular}

Conclusion

This article addresses a basic, but essential, issue of global constitutionalization, thus far neglected by scholars of international relations, and argues that this originally legal concept requires a consistent definition that would enable scholars of international relations, as well as of comparative politics, to examine, in an empirical manner, its significance with regard to the changing international order. The purpose of this article was to explore a consistent and operational framework of global constitutionalization. Such a framework should take into account the diversity of the international order, but at the same time not reduce its meaning to an overly exclusive definition.

Starting from the nation-state setting, three fundamental constitutional elements have been identified: the formal principle of the international rule of law, the substantive dimension representing human rights provisions, and the time factor allowing for gradual emergence of a global constitutional order. Drawing a 
parallel to the developments of domestic law, I distinguished among three types of global constitutionalization: formal constitutionalization, suggesting the institutionalization of procedural guidelines for interstate relations; substantive constitutionalization, indicating the institutionalization of human rights provisions for individuals comprising civil-political and socio-economic rights; and encompassing global constitutionalization, implying the simultaneous emergence, creation, and identification of formal and substantive international norms.

This article neither proves the existence of global constitutionalization nor examines which national and international conditions might favor or hinder the emergence of a global constitution. But it provides some structural guidance on how to make operational the concept of global constitutionalization and thereby make it empirically approachable by scholars of international relations and political science. So far, studies concerned with global constitutionalization have mainly approached this subject area from a normative angle. Since the concept has a strong anchor in international law, this is not surprising. Almost no attempts have been made to assess the process of global constitutionalization empirically. The exceptions are studies conducted in the European context. ${ }^{80}$

This article offers some guidelines for making this framework operational insofar as it distinguishes among elements embedded in the concept of global constitutionalization. As outlined above, these constitutional elements refer, in general, to norms. The most conventional norms on the international plane are international agreements. ${ }^{81}$ International agreements have some common elements. They are written and binding instruments that establish legal rights and

80. See, e.g., Alec Stone Sweet, Governing with Judges: Constitutional Politics in Europe (2000); Rittberger \& Schimmelfennig, supra note 42. These studies demonstrate that constitutionalization as an ongoing project is empirically quantifiable when compared to the normative concept of constitutionalism. They also demonstrate that constitutional mechanisms, such as judicialization and politicization of policymaking (STONe SwEet, supra), as well as parliamentalization and institutionalization of human rights (Rittberger \& Schimmelfennig, supra note 42), have an impact on European Union and member-state politics.

81. By "international agreement" I refer to international norms. International agreements embrace the widest range of international instruments, including treaties, conventions, charters, and covenants, which are rather formal and universal, covering a relatively broad range of functional areas, as well as protocols and amendments that generally refer to less formal agreements. Following the Vienna Convention on the Law of Treaties, art. 2(1)(a), May 23, 1969, 1155 U.N.T.S. 331, an "international agreement" is "concluded between States in written form and governed by international law, whether embodied in a single instrument or in two or more related instruments and whatever its particular designations[.]" See International Law Documents 129 (Malcolm D. Evans ed., 8th ed. 2007). 
duties and require ratification ${ }^{82}$ by state parties. National ratification behavior might be an essential starting point for an empirical examination of global constitutionalization. Although studies concerned with the issue of state commitment to international agreements are frequent in the field of international relations, they tend to focus on one agreement or a small selection of agreements. ${ }^{83}$ With regard to global constitutionalization, a more appropriate structure would need to provide for a "multi-treaty" framework and allow one to study "cross-treaty" ratification behavior. So far, no systemic analyses providing for such a multi-treaty framework have been conducted. To this end, it would be necessary to compile suitable data on the ratification of international agreements relevant to the concept of global constitutionalization.

This article offers some direction for the selection of international agreements relevant to the concept of global constitutionalization. Given that the legal elements central to global constitutionalization have been defined as international norms containing formal guidelines for interstate relations on the one hand, and substantive fundamental human rights provisions for individuals (covering the first and second generation of human rights) on the other, systematic empirical investigation of global constitutionalization should in particular focus on a choice of international agreements having these constitution-like characteristics. ${ }^{84}$

Certainly, by focusing on the ratification of constitution-like international

82. "Ratification" means several possible treaty actions-acceptance, approval, and accessionthat have the same legal effect as ratification and lead to an internationally binding arrangement. Vienna Convention, supra note 81 , art. 2(1)(b).

83. See, e.g., Jay Goodliffe \& Darren G. Hawkins, Explaining Commitment: States and the Convention Against Torture, 68 J. Pol. 358 (2006); Emilie M. Hafner-Burton \& Kiyoteru Tsutsui, Human Rights in a Globalizing World: The Paradox of Empty Promises, 110 Aм. J. Soc. 1373 (2005); Oona A. Hathaway, Why Do Countries Commit to Human Rights Treaties?, 51 J. Conflict Resol. 588 (2007); Eric Neumayer, Death Penalty Abolition and the Ratification of the Second Optional Protocol, 12 INT'L J. Hum. RTs. 3 (2008); Beth Simmons, International Law and State Behavior: Commitment and Compliance in International Monetary Affairs, 94 AM. Pol. Scr. Rev. 819 (2000); James R. Vreeland, Political Institutions and Human Rights: Why Dictatorships Enter into the United Nations Convention Against Torture, 62 INT'L Org. 65 (2008); Christine Min Wotipka \& Franzisco O. Ramirez, World Society and Human Rights: An Event History Analysis of the Convention on the Elimination of All Forms of Discrimination Against Women, in The Global Diffusion of Markets and Democracy 303 (Beth Simmons et al. eds., 2008).

84. Note that the number of international agreements in force is incredibly large and increasing. See JACKson, supra note 56, at 42. A few examples representing some constitution-like elements on the international plane are the U.N. Charter, core human rights treaties with amendments and optional protocols, the Geneva Conventions, the Vienna Convention on the Law of Treaties, the Convention on the Law of the Sea, the General Agreement on Tariffs and Trade, the Agreement Establishing the WTO, and fundamental international labor conventions. 
agreements, only part of the constitutionalization process can be captured. Such an approach does not capture global constitutionalization characteristics like societal forces and judicial review. Nonetheless, ratification of quasi-constitutional agreements represents a conditio sine qua non for the emergence of a global constitutional order, and a feasible starting point for empirical research.

In studying a systematic, multi-treaty global constitutionalist framework, three questions could be tackled empirically. First, we might address the issue of whether the process of global constitutionalization is actually taking place a round the globe, measuring the frequency and pace of national commitment to international, constitution-like agreements over time and space. Second, following the normative distinction between global constitutional unity and global constitutional pluralism, we might study which constitutional model-the unitary or the pluralist (differentiating between the formal and substantive, and in turn, the civil-political and socio-economic constitutional processes) - is best suited to describe real developments in international law. Finally, moving beyond mere descriptive research objectives, empirical analysis should be able to identify forces impeding or facilitating constitutionalization processes on the global scale by examining the effects of specific national and international conditions on national commitment to these constitution-like international agreements.

This article does not claim that this constitutional scaffold and the study of state commitment to international constitution-like agreements represent global constitutionalization with its all-embracing characteristics. This formulation captures only part of the larger constitutional picture. As such, it ignores structural issues of global authority, including principles and structures for the establishment of global legislation, the exercise of global executive power, and the operation of global adjudicatory capacity. Furthermore, such a conceptualization omits the role of societal forces, like non-governmental organizations, transnational actors, or public-private partnerships, in the international system. ${ }^{85}$ However, it might provide for a first empirical insight into the pace and process of global constitutionalization and thus deepen our understanding of the phenomenon.

85. As lawyers with a systems theory background argue, the process of global constitutionalization not only incorporates states, but also societal forces. See, e.g., Civilizing World Society, supra note 53; Meyer, supra note 53; Teubner, supra note 36; Teubner, supra note 51. Cohen counters that the importance of these newly emerging societal forces is overestimated by systems theorists. According to Cohen, the "international society of states," in contrast to the cosmopolitan order of societal forces, remains the core of the world political system. It aims first and foremost at the coordination of the two main principles as evident in international relations today: sovereign equality of states and fundamental human rights. See Cohen, supra note 4, at 13, 24. 